\title{
Land spreading of solar-dried citrus peel to control runoff and soil erosion
}

\author{
G. Bombino, P. Denisi, D. Fortugno, V. Tamburino, \\ D. A. Zema \& S. M. Zimbone \\ Mediterranean University of Reggio Calabria, \\ Department of Agro-forest and Environmental Science and Technology, \\ Italy
}

\begin{abstract}
Marginal areas of southern Italy are often characterised by steep slopes and scarce vegetal coverage, which induce relevant runoff and soil erosion phenomena. On the other hand, the agricultural system of some Italian regions is characterized by the presence of many citrus industries, producing high amounts of by-products and wastewater. The possibility of spreading orange peel over land could represent an alternative solution for a more sustainable biomass disposal and, at the same time, protect against the risks soil erosion in Mediterranean areas.

This paper reports the results of an experimental research activity aimed at evaluating the hydrological effects of land spreading of solar-dried citrus peel over steep plots (remodelled at $100 \%$-slope), containing bare soil or covered by vegetation and exposed to natural rainfalls. The comparison of hydrological observations to those performed on untreated soils ("control") highlighted that the addition of citrus peel to soil induced an appreciable reduction of runoff and particularly of sediment yield, due to the improvement of the soil properties, which encourages the establishment and development of vegetation.
\end{abstract}

Keywords: soil conservation, orange peel, runoff, sediment yield, vegetal coverage.

\section{Introduction}

The lack of vegetal coverage, together with the slope steepness, induces heavy erosion phenomena in marginal areas as well as in the artificial banks of roads, 
reservoirs, dumps, quarries, etc., which can compromise work functionality (Morgan [15]) in addition to other strong environmental impacts on landscape.

Several experimental investigations have allowed one to arrange proper techniques assuring soil conservation in artificial steep slopes (Schiechtl and Stern [20]). From these researches the fundamental role played by vegetation in facing water runoff and soil erosion is evident (Morgan [15]). Most of the proposed techniques simulate the protective action of vegetation (e.g. geosynthetic and natural materials) or encourage its establishment and development (e.g. hydro-seeding, straw-bitumen mulching, etc.) (Khan et al. [8]). However such techniques, providing good performance in a humid climate, are often difficult to apply in the Mediterranean semi-arid conditions typical of southern Italy.

Beside the protective action induced on lands by an extended vegetal coverage, a high organic matter (OM) content generally improves the physical, chemical and biological properties of soil (in particular increasing its macroporosity and infiltrability and decreasing aptitude to seal formation (Chaney and Swift [3]; Cox et al. [4]; Le Bissonais [12])) and encourages the establishment and development of the vegetal coverage. Such effects, particularly remarkable in the steep slopes of Mediterranean areas where soils are often poor in OM, help to reduce runoff and soil erosion.

On the other hand, the agricultural system of Southern Italy (mainly the Sicily and Calabria regions) is characterized by the presence of citrus processing industries, which produce high amounts of citrus peel (about $100.000 \mathrm{t} \mathrm{year}^{-1}$ of dry matter): this by-product has a low commercial value on the markets due to the high water content, which makes expensive biomass storage and transportation (Tamburino and Zema [23]).

The utilisation of citrus peel as a soil organic conditioner (preferably solardried after land disposal, in order to reduce drying-up and transportation costs, Kimball [9]; Tamburino and Zimbone [22]) could assure not only a proper valorisation of this by-product, but also an environmentally sustainable technique to protect marginal and steep slopes in the Mediterranean environment against risks of soil erosion (Tamburino and Zimbone [22]), due to the high content of OM (about $900 \mathrm{~g}$ per kg of dry matter, Tamburino and Zema [23]).

In relation to these considerations, this paper aims at evaluating the protective action induced by the addition of solar-dried orange peel on artificial steep slopes with particular reference to the effects on soil properties and vegetation characteristics.

\section{Materials and methods}

The investigation has been carried out in the experimental farm of the Mediterranean University of Reggio Calabria (Southern Italy), located at an altitude of $250 \mathrm{~m}$ a.s.l., fig. 1. Climatic characteristics of this area are typical of the Mediterranean basin, with mild rainy winters and warm dry summers; the experimental site falls within the phyto-climatic plan defined as "thermoMediterranean, dry sub-humid ombro-type" (Piussi [17]). 

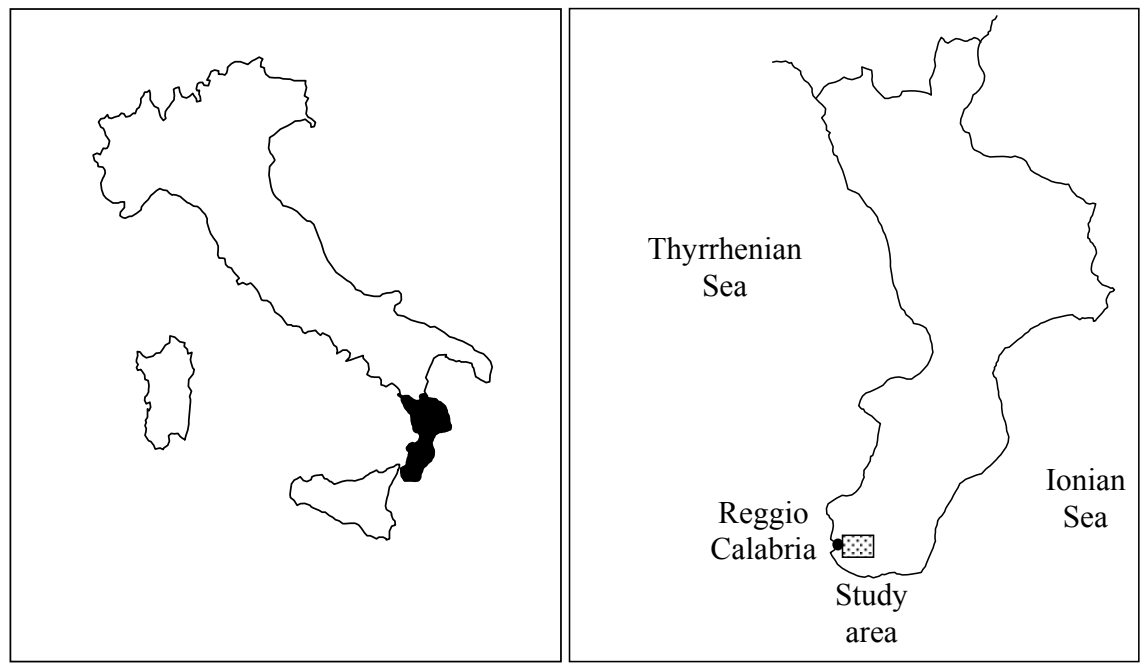

Figure 1: $\quad$ Location of the study area.
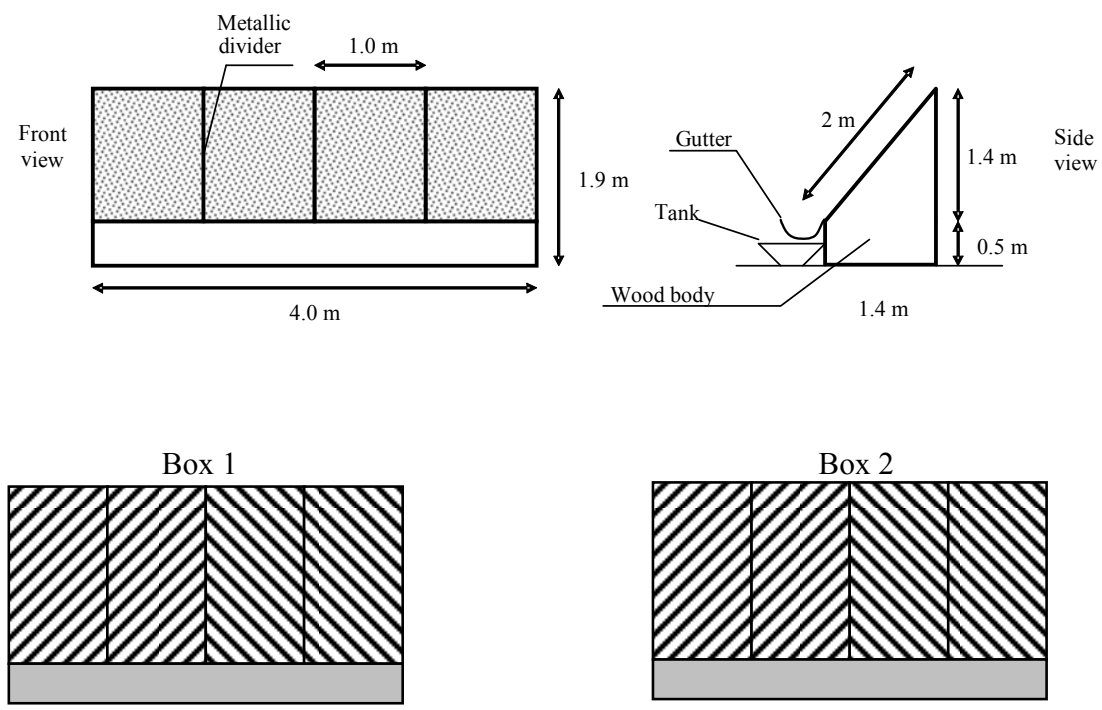

Soil treated with solar-dried orange peel

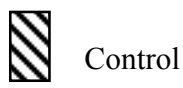

Figure 2: Scheme of the plots arranged for the experimental investigation. 
Eight plots, each one covering an area of $2 \mathrm{~m}^{2}$, were remodelled (slope equal to $100 \%$ ) in two wood boxes. The plots were hydraulically isolated by metal dividers (40-cm high and $20-\mathrm{cm}$ deep in the soil) and a channel, located immediately below the bottom side of the box and linked to a tank, collected surface runoff volumes and sediment yields, fig. 2 .

In each plot a $40-\mathrm{cm}$ deep layer of agricultural soil was overlain on a $10-\mathrm{cm}$ layer of gravel. The agricultural soil was characterised by an average weight

Table 1: Values of the hydrological observations performed in the experimental investigation.

\begin{tabular}{|c|c|c|c|c|c|c|c|c|c|c|}
\hline \multirow{3}{*}{ Event } & \multicolumn{2}{|c|}{ Rainfall } & \multicolumn{4}{|c|}{ Runoff } & \multicolumn{4}{|c|}{ Sediment } \\
\hline & \multirow{2}{*}{$\begin{array}{l}\text { height } \\
(\mathrm{mm})\end{array}$} & \multirow{2}{*}{$\begin{array}{c}\text { mean } \\
\text { intensity } \\
(\mathrm{mm} / \mathrm{h})\end{array}$} & \multicolumn{2}{|c|}{$\begin{array}{l}\text { volume } \\
(\mathrm{mm})\end{array}$} & \multicolumn{2}{|c|}{$\begin{array}{l}\text { coefficient } \\
(\%)\end{array}$} & \multicolumn{2}{|c|}{$\begin{array}{l}\text { yield } \\
(\mathrm{t} / \mathrm{ha})\end{array}$} & \multicolumn{2}{|c|}{$\begin{array}{c}\text { concentration } \\
(\mathrm{g} / \mathrm{l})\end{array}$} \\
\hline & & & $\mathrm{T}$ & $\mathrm{C}$ & $\mathrm{T}$ & $\mathrm{C}$ & $\mathrm{T}$ & $\mathrm{C}$ & $\mathrm{T}$ & $\mathrm{C}$ \\
\hline 1 & 4.1 & 1.0 & 0.6 & 0.5 & 14.0 & 12.9 & 0.8 & 1.2 & 139 & 227 \\
\hline 2 & 80.0 & 18.2 & 24.1 & 23.9 & 30.1 & 29.9 & 35.4 & 76.5 & 147 & 320 \\
\hline 3 & 60.0 & 16.7 & 17.0 & 16.9 & 28.4 & 28.2 & 5.4 & 12.4 & 32 & 73 \\
\hline 4 & 4.3 & 1.8 & 2.3 & 2.5 & 54.3 & 57.4 & 0 & 0.7 & 0 & 29 \\
\hline 5 & 12.4 & 2.4 & 2.2 & 2.6 & 17.5 & 20.6 & 0 & 0 & 0 & 0 \\
\hline 6 & 22.4 & 5.6 & 6.7 & 7.0 & 30.1 & 31.1 & 6.8 & 13.2 & 102 & 189 \\
\hline 7 & 22.2 & 1.3 & 5.0 & 6.1 & 22.4 & 27.4 & 1.7 & 3.0 & 35 & 50 \\
\hline 8 & 9.4 & 0.5 & 2.5 & 3.3 & 27.0 & 35.5 & 0 & 0 & 0 & 0 \\
\hline 9 & 14.3 & 1.7 & 4.0 & 4.3 & 27.8 & 29.8 & 0 & 0 & 0 & 0 \\
\hline 10 & 10.6 & 3.0 & 4.8 & 5.0 & 44.9 & 47.6 & 1.4 & 2.7 & 30 & 54 \\
\hline 11 & 5.3 & 1.9 & 1.6 & 1.8 & 31.0 & 33.5 & 0 & 0 & 0 & 0 \\
\hline 12 & 55.0 & 15.5 & 16.5 & 19.2 & 30.1 & 35.0 & 15.7 & 49.5 & 95 & 257 \\
\hline 13 & 5.0 & 1.3 & 0.9 & 1.4 & 18.7 & 27.8 & 0 & 0 & 0 & 0 \\
\hline 14 & 62.4 & 14.4 & 5.5 & 6.1 & 8.9 & 9.8 & 3.6 & 20.7 & 65 & 340 \\
\hline 15 & 65.1 & 19.3 & 3.2 & 4.2 & 4.9 & 6.5 & 9.6 & 11.2 & 298 & 267 \\
\hline 16 & 60.6 & 12.1 & 5.5 & 5.8 & 9.0 & 9.6 & 10.9 & 13.4 & 199 & 231 \\
\hline 17 & 50.3 & 12.7 & 5.0 & 5.8 & 10.0 & 11.5 & 12.4 & 16.7 & 247 & 288 \\
\hline 18 & 18.2 & 10.8 & 1.8 & 2.9 & 10.0 & 15.9 & 0.7 & 11.4 & 37 & 394 \\
\hline 19 & 20.7 & 14.0 & 3.2 & 3.5 & 15.3 & 16.7 & 6.1 & 11.0 & 193 & 320 \\
\hline 20 & 31.1 & 11.8 & 2.6 & 2.8 & 8.3 & 8.8 & 4.2 & 10.6 & 163 & 387 \\
\hline
\end{tabular}

Note: $\mathrm{T}=$ treated plots; $\mathrm{C}=$ control plots. 
content of OM equal to $1.3 \%$ and the following grain size fractions (USDA soil classification): $59 \%$ sand, $29 \%$ silt and $12 \%$ clay.

Solar-dried orange peel, previously shredded $(4<\phi<8 \mathrm{~mm})$, was incorporated at a dose of $3 \mathrm{~kg} / \mathrm{m}^{2}$ in the 3 -cm deep surface layer of four plots (in the following indicated as "treated soils"). The remaining four plots (not treated) were considered as control.

All plots were exposed to natural rainfalls, recorded by a rain gauge within the experimental farm. During the monitoring period 20 rainfalls (varying between 4 and $80 \mathrm{~mm}$ ) were recorded: 13 events on plots with bare soil and further 7 on vegetated plots with a coverage between 8 and $23 \%$ of the total plot area. The height and mean intensity of rainfall records are reported in table 1.

The surveys performed on surface runoff volumes and sediment yields were referred to an area of $1.4 \mathrm{~m}^{2}$, representing the projection of the plot surface on a horizontal plane; when it was impossible, the cumulated height of more rainfalls (with a maximum of 3 events) was surveyed. Sediment yield was measured by weighing the eroded soil after oven-drying at $105^{\circ} \mathrm{C}$.

Vegetation species, classified within the families of Cruciferae, Euphorbiaceae, Oxalidaceae, Graminaceae, Compositae and Asteraceae, were periodically characterised by visual estimates of the vegetal canopy cover through the grid method (Vogel [24]).

\section{Results and discussion}

\subsection{Hydrological effects on bare soil}

Table 1 reports the values of the 13 hydrological observations (following rainfall events with a total height of $305 \mathrm{~mm}$ ) recorded on plots containing bare soil.

The plots treated with solar-dried orange peel were characterised by values of runoff volume and coefficient slightly lower (on the average by 10\%) than those recorded for not treated plots (control), with a maximum difference up to $33 \%$, table 1 and fig. 3 . The reduction was more remarkable for soil erosion: on treated soils the values of sediment yield and concentration were basically lower (on the average by $55-60 \%$ ) than control plots, table 1 and fig. 4 . In 5 cases no sediment yields were recorded (corresponding to rainfall height lower than $14 \mathrm{~mm}$ ).

The positive effects induced on runoff and sediment yield recorded in treated soils can be presumably ascribed to the amending action of the orange peel added to the soil, which increased soil infiltrability and water retention and improved aggregate stability (Barthés and Roose [1]).

\subsection{Hydrological effects in vegetated soils}

Table 1 reports the values of the 7 hydrological observations (following rainfall events with a total height of $308 \mathrm{~mm}$ ) recorded in plots covered by spontaneous vegetation.

Also for this monitoring period the results of the investigation confirm the positive effects surveyed in plots with bare soil due the biomass addition to soil. 


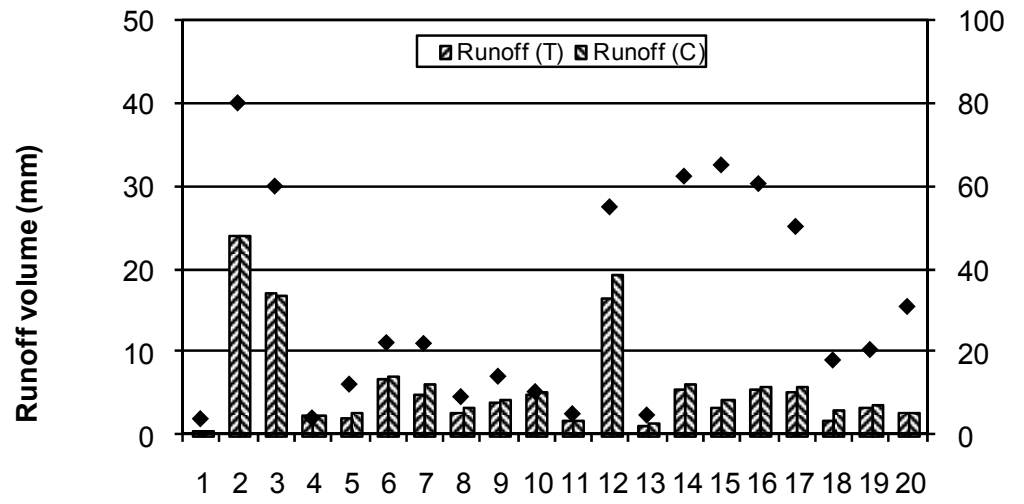

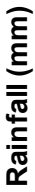

\section{Event}

Figure 3: Comparison of surface runoff volumes in the experimental plots for the 20 observed events $(\mathrm{T}=$ treated plots; $\mathrm{C}=$ control plots $)$.

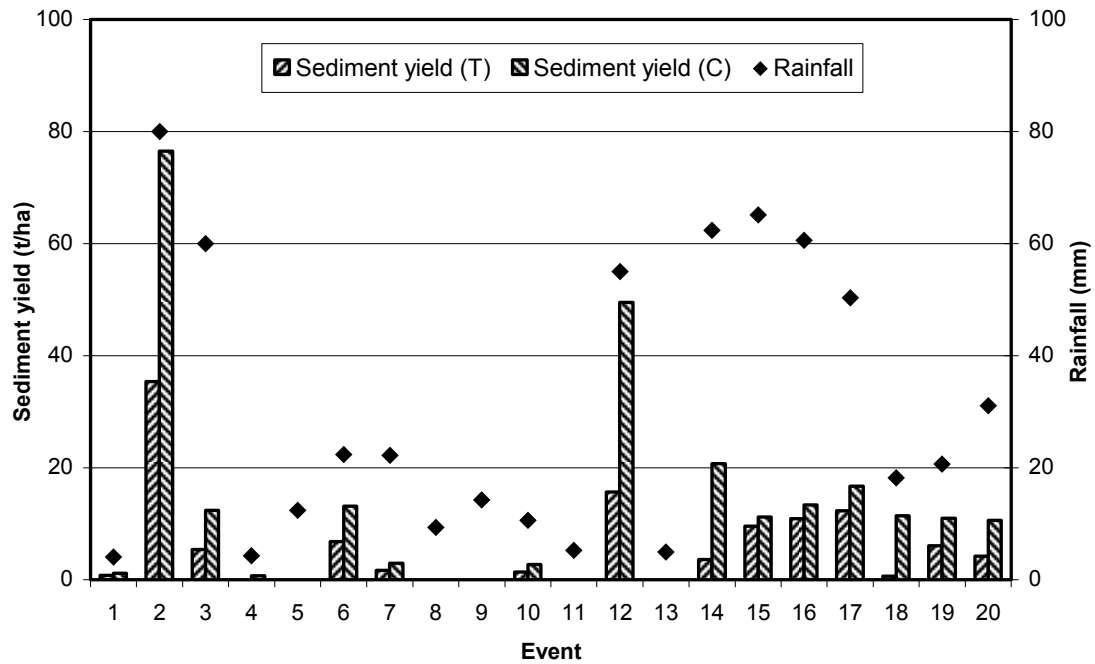

Figure 4: Comparison of sediment yields in the experimental plots for the 20 observed events $(\mathrm{T}=$ treated plots; $\mathrm{C}=$ control plots $)$.

The values of the vegetal canopy cover were generally higher in plots treated with orange peel (on the average $20 \%$ against $13 \%$ surveyed in control soils); as found by other Authors (Vogel [24]; Lesoing and Doran [13]; Edmeades [25]), it can be presumably ascribed to the better edaphic conditions for vegetation growth induced by the addition of OM contained in orange peel. Surveys on vegetal species grown in the experimental plots highlighted a greater biodiversity in treated plots, shown by the presence of 10 species of 7 different families. 


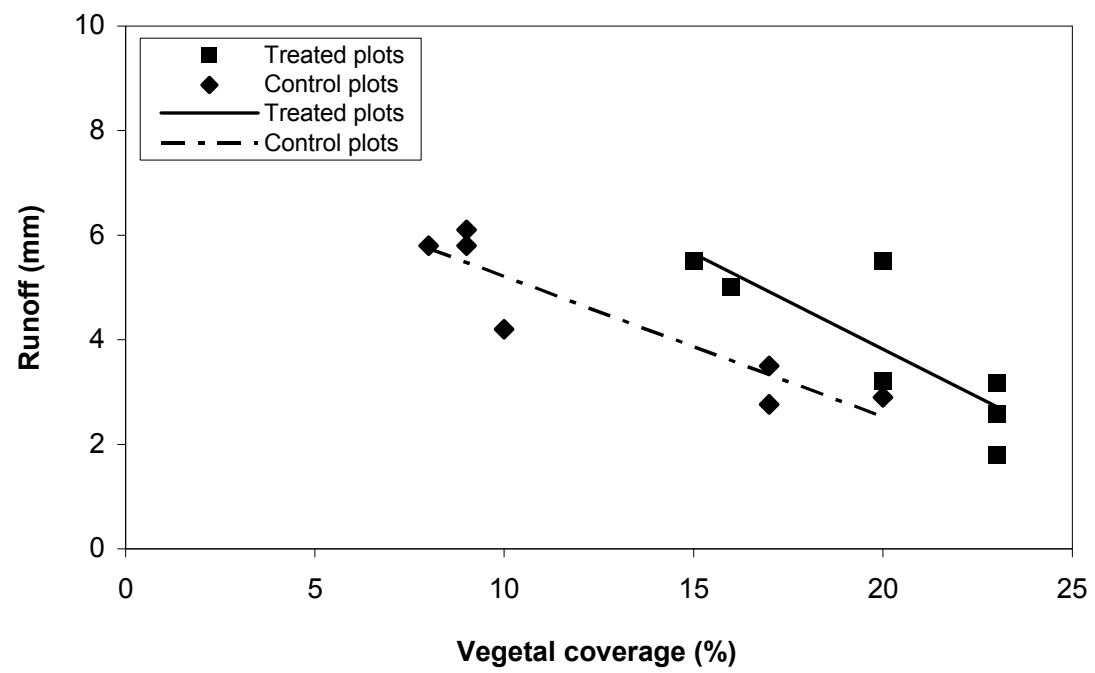

Figure 5: Relationships between the surface runoff volume and the vegetal coverage surveyed on the experimental plots (seven observations).

The higher vegetal canopy cover surveyed in treated plots induced a noticeable protective action on the soil, determining, in comparison to control plots, a mean reduction of about $15 \%$ in runoff volume, with a maximum deviation of $37 \%$, table 1 and fig. 3 . Similar results were reported in other works, which highlighted reductions of runoff volumes up to $40 \%$ (Deuchras et al. [5]; Casermeiro et al. [2]) resulting from the higher vegetal coverage. Surface runoff in both experimental theses was higher at the beginning of the observation period (November-early December) in relation to the scarce vegetal coverage; in these months, as expected, the values of the runoff coefficient were higher. Since January, in correspondence to the higher vegetal coverage, the runoff volume (and consequently its coefficient) underwent a relevant decrease.

Figure 5 shows the good correlations between the surface runoff and the vegetal canopy cover for both treated soils $\left(\mathrm{r}^{2}=0.68\right)$ and control plots $\left(\mathrm{r}^{2}=\right.$ $0.84)$.

As expected, in treated plots a relevant reduction of sediment yield (on the average by $50 \%$ and in 3 cases by $60 \%$ or more) was surveyed with respect to control soils, table 1 and fig. 4. The protective action induced by vegetation, beside the improvement of the physical and chemical properties of soils due to the biomass addition (already highlighted in the surveys performed on bare soils), contributed to reduce sediment concentration in the collected runoff volumes (on the average by 40\%): this result matches the outcomes of other Authors (Mueller-Dumbois and Ellemberg [16]; Elwell and Stocking [7]; Riezebos and Epema [18]; Smith and Mullins [21]; Sanchez and Puigdefabregas [19]; Deuchras et al. [5]; Lasanta et al. [11]; Barthés and Roose [1]; Casermeiro et al. [2]) in relation to sediment yield observed in artificial or natural slopes with 


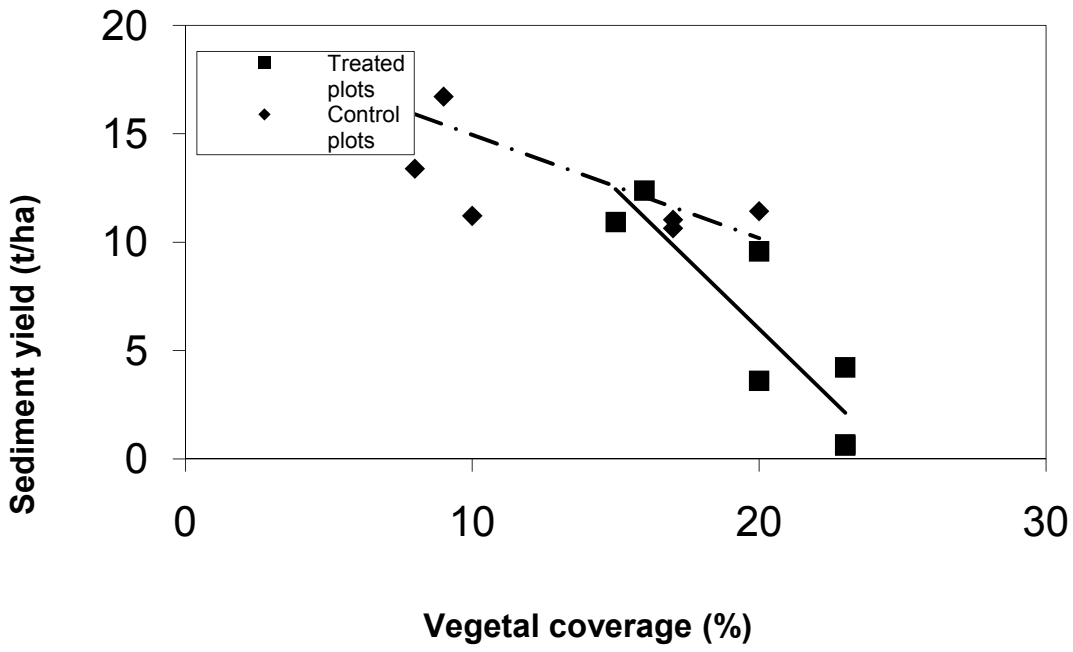

Figure 6: Relationships between the sediment yield and the vegetal coverage surveyed on the experimental plots (seven observations).

different vegetal coverage and exposed both to natural and simulated rainfalls. The correlation between the sediment yield and the vegetal canopy cover was evident only for treated soils $\left(r^{2}=0.78 ; r^{2}=0.39\right.$ for control plots), fig. 6 .

Sediment yield was high until vegetation was not able to cover the whole plot surface; however in this period a strong decrease of sediment yield was recorded (about 3.5 times) on treated soils: it can be explained by the persistence of the positive effect induced by orange peel addition on the physical properties of treated soils and not yet affected by the presence of vegetation (McLaren and Cameron [14]; Johnston [10]).

\section{Conclusions}

The performed experimental investigation allows one to draw indications about the utilisation of solar-dried citrus peel for soil conservation in Mediterranean environment.

The results achieved through the monitoring of hydrological response of artificial slopes treated with $3 \mathrm{~kg} / \mathrm{m}^{2}$ of solar-dried orange peel highlighted the positive effect on both surface runoff and sediment yield.

On bare soil the addition of orange peel induced a slight reduction of runoff volumes and a more remarkable decrease of sediment yield, attributable to the lower values of sediment concentration in runoff volumes. This protective action became more relevant in soil covered by spontaneous vegetation thanks to the more extended coverage stimulated by orange peel amendment.

On the whole, the treatment of soil surface with biomass contributed to a reduction of runoff volumes by $10 \%$ and of soil erosion by $50 \%$ with respect to 
control soils (not subjected to any treatment) in correspondence to natural rainfall up to $80 \mathrm{~mm}$.

Even though a longer and more detailed investigation is needed to confirm such outcomes and validate this practice on soils of different geomorphologic characteristics, the utilisation of this by-product (widely available at low cost within the agro-industrial system of Southern Italy) for soil conservation in steep and marginal slopes seems to represent a valid alternative to other traditional techniques arranged in different environmental contexts.

\section{Acknowledgement}

This work was carried out with equivalent contributions of the authors.

\section{References}

[1] Barthès, B. and Roose, E., Aggregate stability as indicator of soil susceptibility to runoff and erosion: validation at several levels. Catena, 47, 133-149, 2002.

[2] Casermeiro, M.A., Molina, J.A., De La Cruz Caravaca, M.T., Hernando Costa, J., Hernando Massanet M.I., Moreno P.S., Influence of shrubs on runoff and sediment loss in soils of Mediterranean climate. Catena, 57, 91107, 2004.

[3] Chaney, K. and Swift, R.S., The influence of organic matter on aggregate stability in some British soil. European Journal of Soil Science, 35 (2), 223230, 1984.

[4] Cox, L., Becker, A., Celis, R., Loperz, R., Hermosin, N.R.C., Cornejo, J., Movement of clopyralid in a soil amended with olive oil mill wastewater as related to soil porosity. Fresenius Environment, 3-4, 167-171, 1996.

[5] Deuchras, S.A., Townsend, J., Aitkenhead, M.J., Fitzpatrick, E.A., Changes in soil structure and hydraulic properties in regenerating rain forest. Soil Use and Management, 15, 183-187, 1999.

[6] Edmeades, D.C., The long-term effects of manures and fertilisers on soil productivity and quality: a review. Nutr. Cycl. Agroecosyst. 66, pp. 165180, 2003.

[7] Elwell, H.A. and Stocking, M.A., Vegetation cover to estimate soil erosion hazard in Rhodesia. Geoderma, 15, 61- 70, 1976.

[8] Khan, M.J., Monke, E.J., Foster, G.R., Mulch cover and canopy effect on soil loss. Transactions of the ASAE, 31 (3), 706-711, 1988.

[9] Kimball, D.A., Citrus Processing - 2nd Edition. Aspen Publishers, Inc. Gaithersburg, MD, USA, 1999.

[10] Johnston, A.E., The value of long-term field experiments in agriculture, ecological and environmental research. Adv. Agron., 59, 291-333, 1997.

[11] Lasanta, T., Garcìa Ruìz, J.M. Pérez-Rontomé, C., Sancho, C., Runoff and sediment yield in a semiarid environment: the effect of land management after farmland abandonment. Catena, 38, 265-278, 2000. 
[12] Le Bissonais, Y., Aggregate stability and assessment of soil crusting and erodibility: 1. Theory and methodology. European Journal of Soil Science, 48, 39-48, 1996.

[13] Lesoing, G.W., Doran, J.W., Crop rotation, manure and agriculture chemical effects on dryland crop yield and SOM over 16 years in East Nebraska. In: Paul E.A., Elliot E.T., Paustian K. and Cole C.V. Eds., Soil Organic Matter in Temperate Agroecosystem. Long-Term Experiments in North America. CRC Press, Boca Raton, Florida, 1997.

[14] McLaren, R.G., and Cameron, K.C., Soil science: sustainable production and environmental protection. Oxford University Press, Auckland, New Zealand, 1996.

[15] Morgan, R.P.C., The nature of soil erosion. Proc. of IECA, Symposium on Soil erosion and its control, London, 21st April, 1989.

[16] Mueller-Dumbois, D., Ellenberg, H., Aims and Methods of Vegetation Ecology. Wiley, New York, 1974.

[17] Piussi, P., Selvicoltura generale, UTET, 1994.

[18] Riezebos, H.T., Epema, G.F., Drop shape and erosivity: Part II. Splash detachment, transport and erosivity indices. Earth Surface Processes and Landforms, 10, 69-74, 1985.

[19] Sanchez, G. and Puigdefabregas, J., Interactions of plant growth and sediment movement on slopes in a semiarid environment. Geomorphology, 9, 243-260, 1994.

[20] Schiechtl, H.M. and Stern, R., Ingegneria naturalistica. Manuale delle opere in terra. Castaldi Ed., Feltre, 1992.

[21] Smith, K. and Mullins, C.E., Soil Analysis Physical Methods. Marcel Dekker Inc., 1991.

[22] Tamburino, V. and Zimbone, S.M., Tecniche di campo per l'essiccazione del pastazzo di arancia. Bollettino della Società Italiana della Scienza del Suolo (S.I.S.S.), Volume 51, 1133-1146, 2002.

[23] Tamburino, V. and Zema, D.A., I sottoprodotti dell'industria di trasformazione: il pastazzo di agrumi. In "Citrus - Trattato di agrumicoltura" (a cura di V. Vacante e F. Calabrese). Il Sole 24 OreEdagricole, 459-470, 2009.

[24] Vogel, W.G., A manual for training reclamation inspectors in the fundamental of soil and revegetation. U.S. Department of Agriculture Forest Service, 1987.

[25] Douglas C. Edmeades (2003). The long-term effects of manures and fertilizers on soil productivity and quality: a review. Nutrient Cycling in Agroecosystems, 66, 165-180. 